Language Learning

Environments 


\section{SECOND LANGUAGE ACQUISITION}

Series Editors: Professor David Singleton, University of

Pannonia, Hungary and Fellow Emeritus, Trinity College,

Dublin, Ireland and Associate Professor Simone E. Pfenninger, University of Salzburg, Austria

This series brings together titles dealing with a variety of aspects of language acquisition and processing in situations where a language or languages other than the native language is involved. Second language is thus interpreted in its broadest possible sense. The volumes included in the series all offer in their different ways, on the one hand, exposition and discussion of empirical findings and, on the other, some degree of theoretical reflection. In this latter connection, no particular theoretical stance is privileged in the series; nor is any relevant perspective - sociolinguistic, psycholinguistic, neurolinguistic, etc. - deemed out of place. The intended readership of the series includes final-year undergraduates working on second language acquisition projects, postgraduate students involved in second language acquisition research, and researchers, teachers and policymakers in general whose interests include a second language acquisition component.

All books in this series are externally peer-reviewed.

Full details of all the books in this series and of all our other publications can be found on http://www.multilingual-matters.com, or by writing to Multilingual Matters, St Nicholas House, 31-34 High Street, Bristol BS1 2AW, UK. 


\section{Language \\ Learning \\ Environments}

Spatial Perspectives on SLA

\section{Phil Benson}

MULTILINGUAL MATTERS

Bristol • Blue Ridge Summit 
DOI https://doi.org/10.21832/BENSON4900

Library of Congress Cataloging in Publication Data

A catalog record for this book is available from the Library of Congress.

Names: Benson, Phil - author.

Title: Language Learning Environments: Spatial Perspectives on SLA/Phil Benson.

Description: Bristol, UK; Blue Ridge Summit: Multilingual Matters, 2021. | Series: Second Language Acquisition: 147 | Includes bibliographical references and index. | Summary: "This book is the first in-depth examination of the application of theories of space to issues of second language learning. The author outlines a new conceptual framework for researching SLA that centres on the idea of 'language learning environments' and demonstrates that where people learn languages is equally as important as how they do so"-Provided by publisher.

Identifiers: LCCN 2021004709 (print) | LCCN 2021004710 (ebook) | ISBN 9781788924894 (paperback) | ISBN 9781788924900 (hardback) | ISBN 9781788924917 (pdf) | ISBN 9781788924924 (epub) |

ISBN 9781788924931 (kindle edition)

Subjects: LCSH: Second language acquisition. | Language and languages-Study and teaching-Methodology. | School environment.

Classification: LCC P118.2 .B465 2021 (print) | LCC P118.2 (ebook) | DDC 401/.93 — dc23 LC record available at https://lccn.loc.gov/2021004709

LC ebook record available at https://ccn.loc.gov/2021004710

British Library Cataloguing in Publication Data

A catalogue entry for this book is available from the British Library.

ISBN-13: 978-1-78892-490-0 (hbk)

ISBN-13: 978-1-78892-489-4 (pbk)

\section{Multilingual Matters}

UK: St Nicholas House, 31-34 High Street, Bristol BS1 2AW, UK.

USA: NBN, Blue Ridge Summit, PA, USA.

Website: www.multilingual-matters.com

Twitter: Multi_Ling_Mat

Facebook: https://www.facebook.com/multilingualmatters

Blog: www.channelviewpublications.wordpress.com

Copyright (C) 2021 Phil Benson.

All rights reserved. No part of this work may be reproduced in any form or by any means without permission in writing from the publisher.

The policy of Multilingual Matters/Channel View Publications is to use papers that are natural, renewable and recyclable products, made from wood grown in sustainable forests. In the manufacturing process of our books, and to further support our policy, preference is given to printers that have FSC and PEFC Chain of Custody certification. The FSC and/or PEFC logos will appear on those books where full certification has been granted to the printer concerned.

Typeset by Deanta Global Publishing Services, Chennai, India. Printed and bound in the UK by the CPI Books Group Ltd.

Printed and bound in the US by NBN. 